\title{
Red wine polyphenols correct vascular function injured by chronic carbon tetrachloride intoxication
}

\author{
Soňa Čačányiová ${ }^{1}$, Olga Pecháňová ${ }^{1}$, Pavel Babál ${ }^{2}$, Andrea Černá2, Pavol Janega ${ }^{1,2}$ and \\ Ramaroson Andriantsitohaina ${ }^{3}$ \\ ${ }^{1}$ Institute of Normal and Pathological Physiology, Centre of Excellence for Cardiovascular Research, Centre of Experimental \\ Medicine, Slovak Academy of Sciences, Sienkiewiczova 1, Bratislava, 813 71, Slovak Republic \\ ${ }^{2}$ Department of Pathology, Faculty of Medicine, Comenius University, Špitálska 24, Bratislava, 813 72, Slovak Republic \\ ${ }^{3}$ Pharmacologie et Physico-chimie des Interactions Cellulaires et Moleculaires, Faculté de Pharmacie, Université Louis \\ Pasteur, URA CNRS 7034, Illkirch, France
}

\begin{abstract}
The aim of the study was to evaluate the effect of red wine polyphenols extract Provinols ${ }^{\mathrm{TM}}$ on the development of cardiovascular injury in the model of carbon tetrachloride $\left(\mathrm{CCl}_{4}\right)$ intoxication. We followed the thoracic aorta vasoactivity and left ventricle nitric oxide $(\mathrm{NO})$ synthase activity in male Wistar rats. In the preventive experiment lasting for 12 weeks the control group, the group receiving $\mathrm{CCl}_{4}(0.5 \mathrm{ml} / \mathrm{kg})$ two times a week subcutaneously, the group receiving Provinols ${ }^{\mathrm{TM}}(30 \mathrm{mg} / \mathrm{kg} / \mathrm{day})$ in drinking water and the group receiving $\mathrm{CCl}_{4}+$ Provinols $^{\mathrm{TM}}$ was used. In the recovery experiment, the initial 12 weeks of $\mathrm{CCl}_{4}$ treatment were followed by 3 weeks of spontaneous recovery or recovery with Provinols ${ }^{\mathrm{TM}}$. $\mathrm{CCl}_{4}$-intoxication resulted in the injury of vasoactivity which was demonstrated by the inhibition of acetylcholine-induced relaxation as well as noradrenaline-induced contraction. In the preventive as well as recovery experiment administration of polyphenols refreshed endotheliumdependent relaxant response and normalized inhibited contraction to adrenergic stimuli. Provinols ${ }^{\mathrm{TM}}$ treatment significantly increased NO-synthase activity in all groups. The results revealed beneficial effects of red wine polyphenols on vascular function injured by chronic $\mathrm{CCl}_{4}$ intoxication. The correction of endothelial function seems to be attributed to the activation of NO pathway by polyphenols.
\end{abstract}

Key words: Red wine polyphenols - Carbon tetrachloride - Rat aorta - Vasoactivity - NO-synthase

\section{Introduction}

Consumption of diets rich in polyphenols, including those obtained in vegetables, fruit and red wine, has been shown to play a role in the maintenance of health and diseases prevention. Many epidemiological studies have suggested that polyphenolic compounds are able to reduce the risk of cardiovascular diseases and to provide protective effect on cardiovascular system (for review, see Zenebe et al. 2001). Moreover, polyphenols help to maintain equilibrium between endothelium-derived vasoconstrictor and vasodilator factors

Correspondence to: Soňa Čačányiová, Institute of Normal and Pathological Physiology, Centre of Excellence for Cardiovascular Research, Centre of Experimental Medicine, Sienkiewiczova 1, 81371 Bratislava, Slovak Republic

E-mail: Sona.cacanyiova@savba.sk in stress (Púzserová et al. 2006). The beneficial effects of these compounds might be explained by wide range of biological pathways. Major activities of plant polyphenols represent the antioxidant properties (Zenebe et al. 2001; Pourahmad et al. 2010). Moreover, polyphenols act on different targets involved in the metabolism of mammalian cells, including nitric oxide (NO) (Stocklet et al. 1999). Our previous experiments using the model of experimental hypertension demonstrated protective effects of red wine polyphenols on increased blood pressure, myocardial fibrosis, vascular wall remodeling and impaired arterial reactivity. Improved vascular function and structure in this model was associated with reduced oxidant status as well as with the increased $\mathrm{NO}$ production after activation of NOsynthase (Bernátová et al. 2002; Pecháňová et al. 2004).

Liver cirrhosis is associated with complex cardiovascular changes and patients with liver cirrhosis due to complex modifications of circulation and neurohormonal changes 
revealed the presence of several potentially important cardiovascular risk predictors for sudden cardiac death and hemodynamic failure (Milovanovic et al. 2009). Moreover, several experimental studies revealed that changes in $\mathrm{NO}$ production and NO level in intra-hepatic and splanchnic circulation seems to be associated with altered liver function and pathogenic processes such as cirrhosis (Wiest and Groszmann 2000). Carbon tetrachloride $\left(\mathrm{CCl}_{4}\right)$, a potent hepatotoxin, nephrotoxin and carcinogen, has been frequently applied for experimental hepatic cirrhosis development (Morales-Ruiz et al. 1996; Thrall et al. 2000; Ogeturk et al. 2005). A mutual relation between hepatic cirrhosis induced by $\mathrm{CCl}_{4}$ and structural changes of blood vessels has been documented by Férnandez-Varo et al. (2007) who showed that conductive vessels of cirrhotic rats undergo an intense process of vascular remodeling. $\mathrm{CCl}_{4}$ intoxication is also associated with chronic modifications in hemodynamics and changes in vascular function (Castro et al. 1994; Mathie et al. 1996a,b; Atucha et al. 2000; Babál et al. 2006). The process of intoxication with this toxic substance includes free radical formation that results in lipoperoxidation and oxidative stress (Abraham et al. 1999). Several natural products having the antioxidant properties, including ginkgo biloba, propolis component and black tea extracts have been reported to reduce $\mathrm{CCl}_{4}$-induced nephrotoxicity and hepatotoxicity (Bahcecioglu et al. 1999; Fadhel and Amran 2002; Ogeturk et al. 2005).

The aim of this work was to investigate the effect of red wine polyphenols extract Provinols ${ }^{\mathrm{TM}}$ on cardiovascular system affected by $\mathrm{CCl}_{4}$ chronic intoxication. The study was focused on the reactivity of thoracic aorta and on the left ventricle NO-synthase activity in rats.

\section{Materials and Methods}

\section{Experimental animals and treatments}

Procedures used were performed in accordance with institutional guidelines and were approved by State veterinary and food administration of the Slovak Republic and by Ethical committee of Slovak Academy of Sciences. All rats were housed under a $12 \mathrm{~h}$ light $/ 12 \mathrm{~h}$ darkness cycle, at a constant humidity and temperature, with free access to standard laboratory rat chow and drinking water. The Institute of Normal and Pathological Physiology provided veterinary care.

Male Wistar rats, 3 month old, were divided into 6 groups, 8 animals in each. The preventive experiment lasting for 12 weeks consisted of four groups: the control group receiving olive oil only, the group receiving $\mathrm{CCl}_{4} 0.5 \mathrm{ml} / \mathrm{kg}$ of body weight twice a week subcutaneously in a $1: 1$ solution with olive oil, the group receiving dried red wine extract
Provinols ${ }^{\mathrm{TM}}$ (40 mg/kg/day) in drinking water and the group receiving Provinols ${ }^{\mathrm{TM}}+\mathrm{CCl}_{4}$. In the recovery experiment, the initial 12 weeks of $\mathrm{CCl}_{4}$ treatment were followed by 3 weeks of spontaneous recovery in the first, and recovery with Provinols ${ }^{\mathrm{TM}}$ administration in the second group of animals. To make sure that each animal received the complete dose of Provinols ${ }^{\mathrm{TM}}$, calculated amount of Provinols ${ }^{\mathrm{TM}}$ was given to each rat in the appropriate volume of water. Daily water consumption was estimated individually for every animal one week before the experiment. During the experiment, water consumption was controlled and Provinols ${ }^{\mathrm{TM}}$ concentration in the drinking fluid was adjusted, if necessary. The red wine extract dry powder Provinols ${ }^{\mathrm{TM}}$ was kindly provided by Mr. D. Ageron (Société Francaise de Distillerie, Vallont Pont d'Arc, France). The following Provinols ${ }^{\mathrm{TM}}$ polyphenols content (in $\mathrm{mg} / \mathrm{g}$ of dry powder) has already been reported: proanthocyanidins 480 , total anthocyanins 61 , free anthocyanins 19 , catechin 38 , hydroxycinnamic acid 18, flavonols 14 (Diebolt et al. 2001).

\section{In vitro study}

For functional study in vitro the thoracic aorta was isolated, cleaned of connective tissue and cut into rings $(3-4 \mathrm{~mm}$ in length). The rings were vertically fixed between two stainless steel wires - triangles in $20 \mathrm{ml}$ incubation organ bath with Krebs solutions of the following millimolar composition: $\mathrm{NaCl} 118 ; \mathrm{KCl} 5 ; \mathrm{NaHCO}_{3} 25 ; \mathrm{MgSO}_{4} 1.2 ; \mathrm{KH}_{2} \mathrm{PO}_{4}$ 1.2; $\mathrm{CaCl}_{2}$ 2.5; glucose 11; ascorbic acid 1.1; $\mathrm{CaNa}_{2}$ EDTA 0.032. The solution was oxygenated with $95 \%$ oxygen and $5 \%$ carbon dioxide and kept at $37^{\circ} \mathrm{C}$. Electromechanical transducer Sanborn FT 10 and potentiometric recorder (Labora) were used for recording of changes in isometric tension. The resting tension was adjusted to $10 \mathrm{mN}$ and applied to each ring. The relaxant responses were followed on the rings precontracted with sub maximal dose of phenylephrine $\left(10^{-5}\right.$ $\mathrm{mol} / \mathrm{l})$ to produce a stabile plateau of contraction. The rings were then exposed to cumulative doses of acetylcholine $(1 \times$ $\left.10^{-8}-3 \times 10^{-5} \mathrm{~mol} / \mathrm{l}\right)$. The extent of relaxation of arterial rings was expressed as a percentage of the phenylephrine-induced contraction. Contractile responses were induced by increasing concentrations of noradrenaline $\left(1 \times 10^{-9}-3 \times 10^{-5} \mathrm{~mol} / \mathrm{l}\right)$ in a cumulative manner and expressed as the developed tension per cross-sectional area of tisue $\left(\mathrm{mN} / \mathrm{mm}^{2}\right)$.

\section{NO synthase activity}

NO synthase activity was determined in crude homogenates of the left ventricles by measuring the formation of $\mathrm{L}-\left[{ }^{3} \mathrm{H}\right]$ citrulline (L-Cit) from L- $\left[{ }^{3} \mathrm{H}\right]$ arginine (Amersham) as previously described by Púzserová et al. (2007). NO synthase activity was expressed as picokatals (pkat) per gram of protein. 


\section{Statistical analysis}

The data were expressed as means \pm S.E.M. For the statistical evaluation of differences between groups, one-way analysis of variance (ANOVA) was used and followed by Bonferroni post-hoc test. The differences of means were considered to be significant at $p<0.05$.

\section{Results}

\section{In vitro vascular reactivity}

In control Wistar rats the application of acetylcholine $\left(10^{-8}-10^{-5} \mathrm{~mol} / \mathrm{l}\right)$ induced concentration-dependent relaxation of thoracic aorta. The chronic treatment with $\mathrm{CCl}_{4}$ significantly inhibited acetylcholine-induced relaxation (Fig. 1). The chronic treatment with Provinols ${ }^{\mathrm{TM}}$ did not affect the relaxant response of thoracic aorta to acetylcholine. On the other hand Provinols ${ }^{\mathrm{TM}}$ treatment prevented the reduction of endothelium-dependent relaxation to

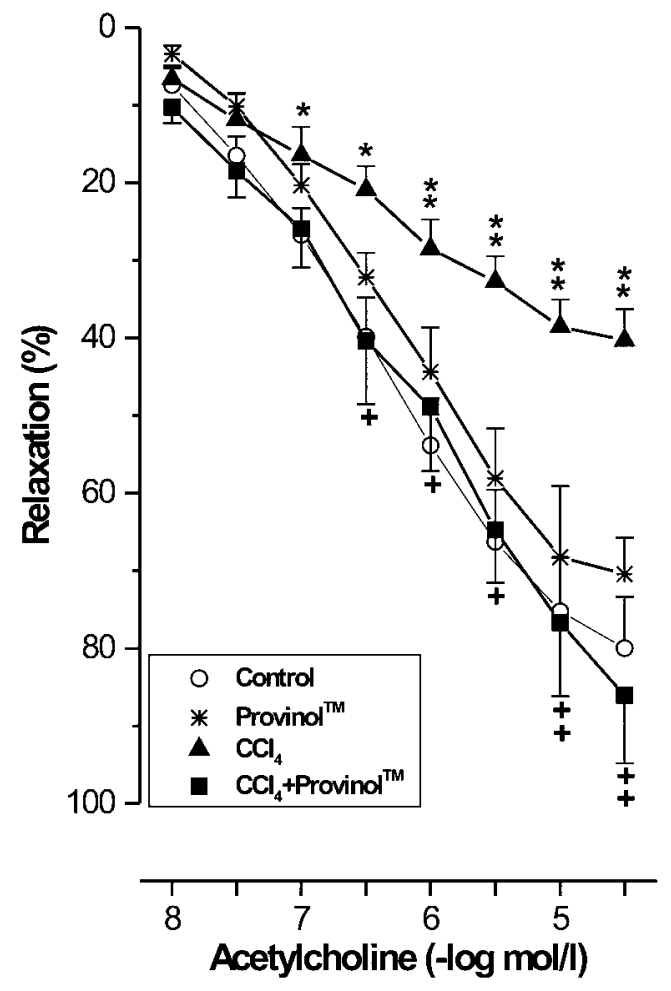

Figure 1. Effect of chronic treatment with red wine polyphenols (Provinol ${ }^{\mathrm{TM}}$ ), carbon tetrachloride $\left(\mathrm{CCl}_{4}\right)$ and simultaneous administration of carbon tetrachloride and provinols $\left(\mathrm{CCl}_{4}+\right.$ Provinol $\left.^{\mathrm{TM}}\right)$ on acetylcholine-induced relaxation of the rat thoracic aorta in Wistar rats. Values are means \pm SEM. ${ }^{\star} p<0.05,{ }^{\star *} p<0.01$ compared with Control group; ${ }^{+} p<0.05,{ }^{++} p<0.01$ compared with $\mathrm{CCl}_{4}$ group. acetylcholine induced by $\mathrm{CCl}_{4}$ treatment and the maximal relaxation was comparable to control (Fig. 1). The response to acetylcholine obtained in the spontaneous recovery group was not significantly different from that of the $\mathrm{CCl}_{4}$-treated group but it was significantly reduced compared with the relaxation of control group (Fig. 2). In contrast, the response to acetylcholine was significantly improved in rings from rats treated with Provinols ${ }^{\mathrm{TM}}$ during recovery period and maximal relaxation was not significantly different from that in control group (Fig. 2).

Noradrenaline induced concentration-dependent contraction in all tested groups. In the $\mathrm{CCl}_{4}$ group, the contractile response was significantly attenuated compared with that in control rats (Fig. 3). Provinols ${ }^{\mathrm{TM}}$ treatment did not modify the concentration-response curve to noradrenaline, but it affects the decreased reactivity of the aorta to noradrenaline induced by $\mathrm{CCl}_{4}$ treatment. There was observed

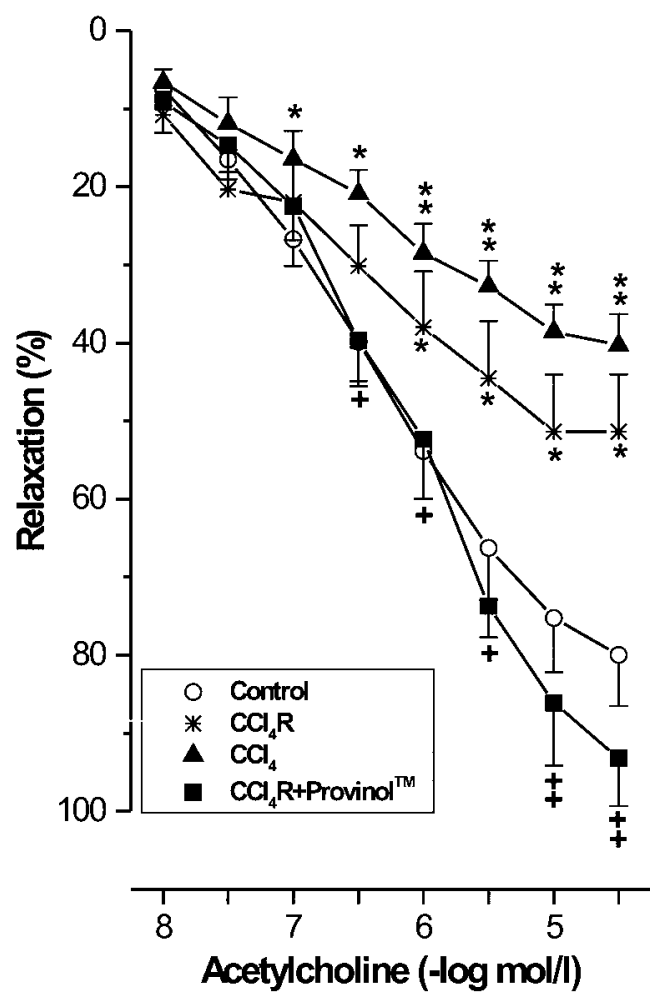

Figure 2. Effect of chronic treatment with red wine polyphenols on relaxant response of the rat thoracic aorta in Wistar rats during recovery period. Concentration-response curves for acetylcholine-induced relaxation of rings taken from control, carbon tetrachloride-treated $\left(\mathrm{CCl}_{4}\right)$, carbon tetrachloride-treated rats followed by 3 -weeks of spontaneous recovery $\left(\mathrm{CCl}_{4} \mathrm{R}\right)$, and carbon tetrachloride-treated rats followed by 3 -weeks treatment with red wine provinols $\left(\mathrm{CCl}_{4} \mathrm{R}+\right.$ Provinol $\left.^{\mathrm{TM}}\right)$ are shown. Values are means \pm SEM. ${ }^{*} p<0.05,{ }^{* *} p<0.01$ compared with Control group; ${ }^{+} p<$ $0.05,{ }^{++} p<0.01$ compared with $\mathrm{CCl}_{4}$ group. 


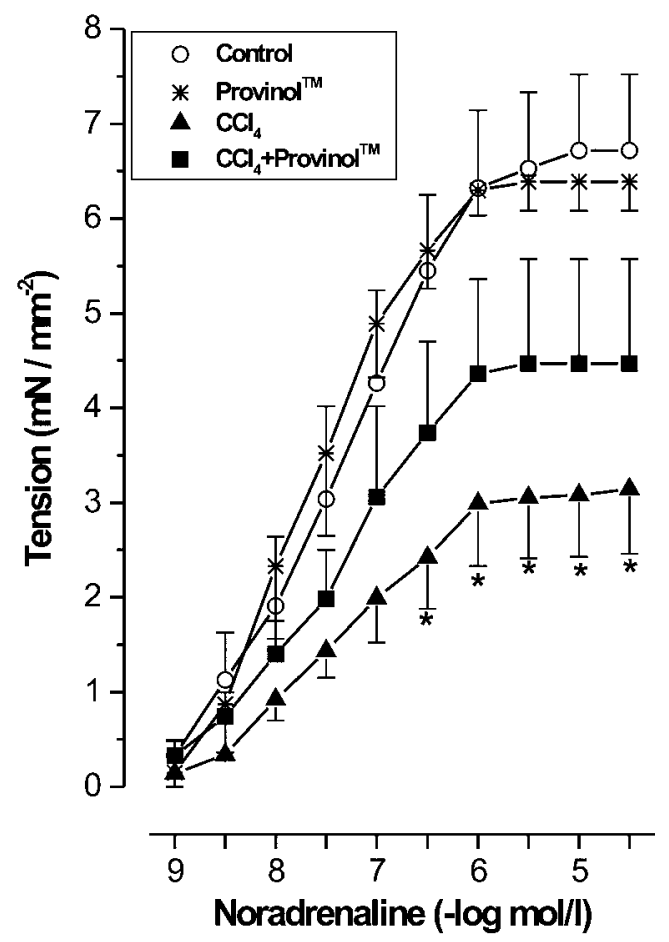

Figure 3. Effect of chronic treatment with red wine polyphenols (Provinol $\left.{ }^{\mathrm{TM}}\right)$, carbon tetrachloride $\left(\mathrm{CCl}_{4}\right)$ and simultaneous administration of carbon tetrachloride and provinols $\left(\mathrm{CCl}_{4}+\right.$ Provinol ${ }^{\mathrm{TM}}$ ) on noradrenaline-induced contraction of the rat thoracic aorta in Wistar rats . Values are means \pm SEM. ${ }^{\star} p<0.05$ with Control group.

no significant difference between contractile responses in control group compared to group contemporary treated with $\mathrm{CCl}_{4}$ and Provinols ${ }^{\mathrm{TM}}$ (Fig. 3). Three weeks of spontaneous recovery did not modify the decreased response to noradrenaline induced by $\mathrm{CCl}_{4}$ treatment (Fig. 4). However, Provinols ${ }^{\mathrm{TM}}$ treatment during recovery period restored the decreased reactivity of the thoracic aorta to noradrenaline induced by $\mathrm{CCl}_{4}$ treatment (Fig. 4).

\section{NO synthase activity}

The results of NO-synthase activity are summarized in Fig. 5. In left ventricles taken from control group, NO-synthase activity was $5.21 \pm 0.22 \mathrm{pkat} / \mathrm{g}$ protein. This parameter was not significantly affected by the treatment with $\mathrm{CCl}_{4}$, activity of NO-synthase represents $4.88 \pm 0.25 \mathrm{pkat} / \mathrm{g}$ protein. However, the treatment with Provinols ${ }^{\mathrm{TM}}$ significantly increased activity of NO-synthase in all groups. After Provinols ${ }^{\mathrm{TM}}$ administration the activity of NO-synthse in left ventricle was significantly increased by $33 \%$ and by $42 \%$ compared to control group $(p<0.01)$ and $\mathrm{CCl}_{4}$ group $(p<0.01)$, respectively. Similarly, the treatment with Provinols ${ }^{\mathrm{TM}}$ during recovery

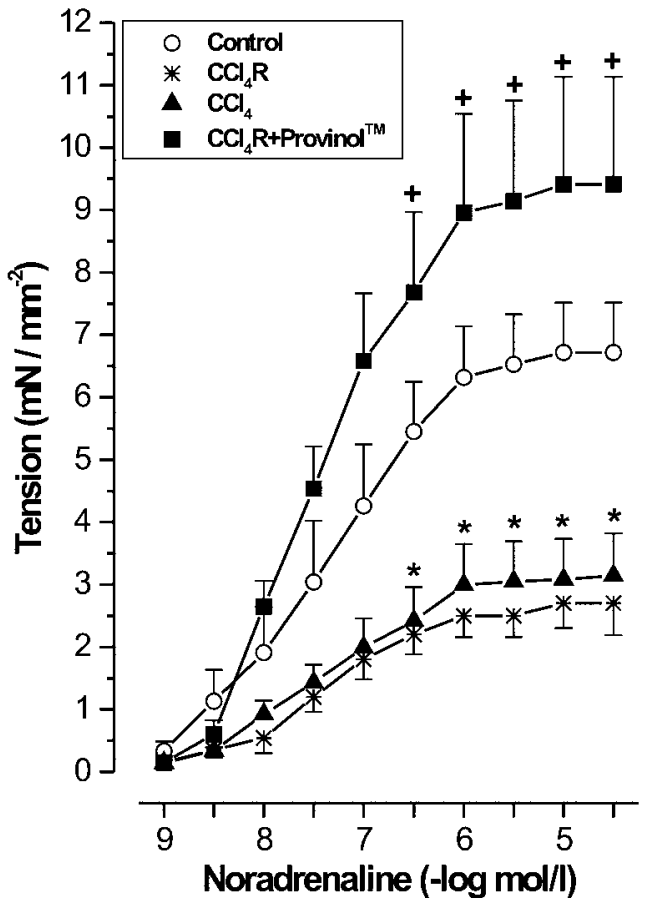

Figure 4. Effect of chronic treatment with red wine polyphenols on contractile response of the rat thoracic aorta in Wistar rats during recovery period. Concentration-response curves for noradrenaline-induced contraction of rings taken from control, carbon tetrachloride-treated $\left(\mathrm{CCl}_{4}\right)$, carbon tetrachloride-treated rats followed by 3 -weeks of spontaneous recovery $\left(\mathrm{CCl}_{4} \mathrm{R}\right)$, and carbon tetrachloride-treated rats followed by 3 -weeks treatment with red wine provinols $\left(\mathrm{CCl}_{4} \mathrm{R}+\right.$ Provinol $\left.^{\mathrm{TM}}\right)$ are shown. Values are means \pm SEM. ${ }^{*} p<0.05$ compared with Control group; ${ }^{+} p<0.05$ compared with $\mathrm{CCl}_{4}$ group.

period significantly increased NO-synthase activity by $35 \%$ and by $44 \%$ compared to control $(p<0.01)$ and $\mathrm{CCl}_{4}$ group $(p<0.01)$, respectively. Simultaneous treatment with $\mathrm{CCl}_{4}$ and Provinols ${ }^{\mathrm{TM}}$ led to the increase in NO-synthase activity by $34 \%$ only with comparison to $\mathrm{CCl}_{4}$ group $(p<0.01)$.

\section{Discussion}

Intoxication by $\mathrm{CCl}_{4}$ which represents a suitable model of system toxicity leading to oxidative damage of different organs is also associated with cardiovascular changes. In this study the chronic treatment with $\mathrm{CCl}_{4}$ induced the significant impairment of endothelial function which was documented by diminished vasorelaxation to acetylcholine in isolated thoracic aorta. This is in a good consensus with previous study which revealed a significant injury of vascular endothelium caused by $\mathrm{CCl}_{4}$. The results documented the significant increase of circulating free endothelial cells 
(endothelemia) and histology of blood vessels showed serious damage to the endothelial cells (Babál et al. 2006) due to oxidative stress (International Programme on Chemical Safety, 1999). Diminished vasoconstriction shown in this study is in an agreement with other studies which referred hyporesponsiveness to different endogenous vasoconstrictors, such as angiotensin II, methoxamine, and noradrenaline in $\mathrm{CCl}_{4}$-induced model of cirrhosis have been claimed in different vascular areas (Castro et al. 1994; Clária et al. 1994; Mathie et al. 1996a,b). Although hyperactivity of vasodilating substances, especially associated with NO overproduction, belongs to the most often hypothesized explanations (Morales-Ruiz et al. 1996; Atucha et al. 2000) none adequate mechanism underlying this phenomenon has been clearly demonstrated. Our experiments revealed that the activity of NO-synthase in the left ventricle was not affected by the treatment with $\mathrm{CCl}_{4}$ and relaxant response to acetylcholine, an activator of NO-synthase was inhibited. Similarly, Mathie et al. (1996a,b) revealed that endothelial NO was unchanged or, if anything, diminished in experimental cirrhosis induced by $\mathrm{CCl}_{4}$ intoxication and did not participate in the decreased response to contractile agonists in mesenteric arterial bed. We suppose that in $\mathrm{CCl}_{4}$-induced model of cirrhosis the release of endothelial NO is inhibited due to endothelium injury so the increase of NO level is not involved in the decreased response of thoracica aorta to noradrenaline and very probably did not play the role in the arterial hyporesponsiveness. Hlavačková et al. (2009) reported that administration of $\mathrm{CCl}_{4}$ led to changes in content of collagen types

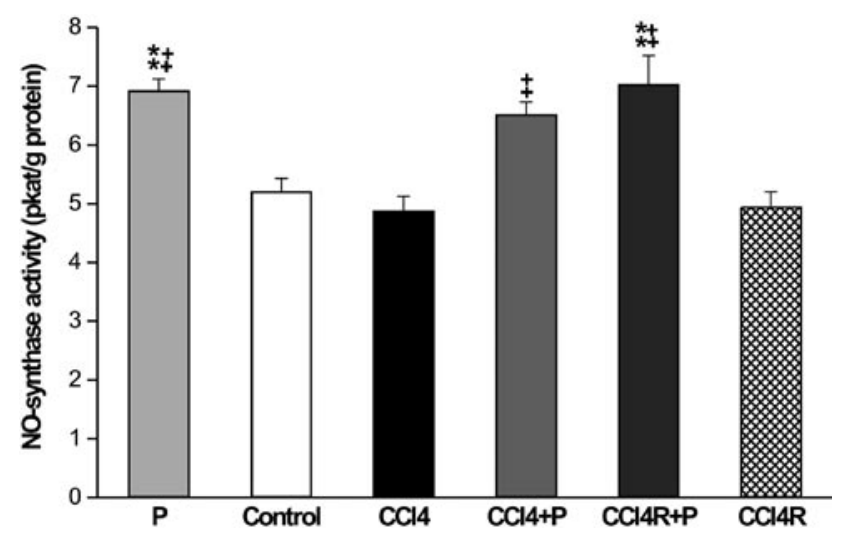

Figure 5. Nitric oxide (NO) synthase activity measured by L-[3H] citrulline formation in the left ventricle in the control group (Control), red wine poplyphenols-treated rats $(\mathrm{P})$, carbon tetrachloridetreated rats $\left(\mathrm{CCl}_{4}\right)$, in rats treated with carbon tetrachloride and red wine polyphenols simultaneously $\left(\mathrm{CCl}_{4}+\mathrm{P}\right)$, in rats after 3 week spontaneous recovery period $\left(\mathrm{CCl}_{4} \mathrm{R}\right)$, and in rats treated with polyphenols during recovery period $\left(\mathrm{CCl}_{4} \mathrm{R}+\mathrm{P}\right) .{ }^{* *} p<0.01$ compared with Control group; ${ }^{++} p<0.01$ compared with $\mathrm{CCl}_{4}$ group. in the aorta and Fitch et al. (2005) showed that increased wall collagen content resulted in the increase in the aortic stiffness which was accompanied by decreased contractile efficiency to different vasoconstrictor agents. We suppose that the decreased contractility of thoracic aorta may be the consequence of arterial wall structural remodeling (such as imbalance in components of extracellular matrix and arterial wall stiffness) due to $\mathrm{CCl}_{4}$ intoxication.

Polyphenolic compounds exert beneficial effect on the cardiovascular system which is mediated mainly by an increase of NO bioavailability and oxygen-free radical scavenging properties in cardiovascular system (Stocklet et al. 1999; Lodovici et al. 2001; Zenebe et al. 2001). Moreover, endothelium protective properties of red wine polyphenols were manifested when decreased endothelemia and histopathological changes in the endothelial lining produced by $\mathrm{CC}_{4}$ were prevented and reduced in according to the treatment with polyphenols extract (Babál et al. 2006). Red wine polyphenols increase NO production, that exerts an anti-apoptotic effect, and it could be responsible for the decrease of endothelemia (Dimmeler and Zeiher 1999). Our functional experiment on the thoracic aorta revealed that the red wine polyphenols were able to restore the relaxation to acetylcholine which was blunted after $\mathrm{CCl}_{4}$ treatment. This indicates that polyphenols really activate endothelial NO-synthase since acetylcholine-induced relaxation of rat thoracic aorta has earlier been demonstrated to be mediated by NO and acetylcholine has been shown as an activator of NO production in conduit artery (Török and Kristek 2001). In addition, we showed that refreshed endothelium-dependent vasorelaxation was accompanied by the increased activity of NO-synthase in the left ventricle after the treatment with Provinols ${ }^{\mathrm{TM}}$. Our results are in a good consensus with observations in the model of NO-deficient hypertension where the potentiation of the inhibited thoracic aorta vasorelaxation has been attributed to the activation of $\mathrm{NO}$ pathway by polyphenols (Bernátová et al. 2002; Pecháňová et al. 2004). Moreover, the increased production of NO due to stimulation of NO-synthase activity in arterial wall (also in aorta) due to the action of polyphenolic compounds has been confirmed by observations of our as well as other laboratories (Stocklet et al. 1999; Zenebe et al. 2001; Benito et al. 2002). Finally, as it is mentioned above, the treatment with $\mathrm{CCl}_{4}$ was associated with destruction of endothelial integrity and the capacity of functional endothelium was decreased so we can suggest that the release of NO was decreased. Moreover, the injury of endothelial cell lining was reported to be associated with an increased production of oxygenfree radicals (Azevedo et al. 2000; Souza et al. 2000) which react with NO and decrease its bioavailability. Polyphenols as scavengers of oxygen free-radicals could play a crutial role in prevention of further NO degradation. The results suggest that the endothelium protective properties and the 
increased activation of NO-synthase activity and/or NO bioavailabilty in the cardiovascular system may be involved in the beneficial effect of the red wine polyphenols in the model of $\mathrm{CCl}_{4}$ intoxication.

The administration of red wine polyphenols in this study also improved the thoracic aorta contractility blunted by $\mathrm{CCl}_{4}$ intoxication. Polyphenols are compounds which readily penetrate into layer of the vessel wall and are easily adsorbed onto the extracellular protein fibers, which organize the vessel layers and so lead to reduced deterioration of the vasculature and the prevention of oxidative damages to cellular membrane (Han et al. 2004). Authors also showed that red wine polyphenols were able to influence the collagen-types content ratio in the wall of the aorta and so positively affect the imbalance in components of extracellular matrix. Moreover, Han et al. (2005) documented that green tea polyphenols prevented appreciable inferiority in such mechanical properties as failure strength, elastic modulus and compliance. Similarly, Mizutani et al. (1999) showed that extract of wine polyphenolics improved aortic fragility and elasticity in stroke-prone spontaneously hypertensive rats. Although the augmentation of blunted contraction after $\mathrm{CCl}_{4}$ intoxication could also be associated with increased production of vasoconstrictor products such as tromboxane $\mathrm{A}_{2}$ induced by polyphenols (Diebolt et al. 2001), the improved vessel contractility after red wine polyphenols administration issued very probably from positive remodeling process in the vascular wall.

In conclusion, subcutaneous application of $\mathrm{CCl}_{4}$ induced injury of vasoactivity in rat thoracic aorta. Red wine polyphenolic compounds revealed protective effects on vascular function in rats intoxicated with $\mathrm{CCl}_{4}$ - the improvement of relaxant as well as contractile properties of arterial wall. The correction of endothelial function after $\mathrm{CCl}_{4}$ intoxication seems to be attributed to the activation of $\mathrm{NO}$ pathway by polyphenols.

Acknowledgment. We thank L. Kosnacova for excellent technical assistance. The presented work was supported by Slovak VEGA 2/0178/09, VEGA 2/0111/11, VEGA 1/0524/08, APVV-0538-07 grant agencies and with the support by the Framework Programme for Research and Technology Development, project: Creation of Centre of Excellency for Sudden Cerebral Vascular Events, Comenius University Faculty of Medicine in Bratislava (ITMS: 26240120015), cofinanced by European Regional Development Fund.

\section{References}

Abraham P., Wifred G., Cathrine S. P. (1999): Oxidative damage to the lipids and proteins of the lungs, testis, and kidney of rats during carbon tetrachloride intoxication. Clin. Chim. Acta 289, $177-179$ doi:10.1016/S0009-8981(99)00140-0
Atucha N. M., Ortíz M. C., Fortepiani L. A., Nadal F. J. A, Martínez-Prieto C., García-Estaň J. (2000): Mesenteric hyporesponsiveness in cirrhotic rats with ascites: role of cGMP and $\mathrm{K}+$ channels. Clin. Sci. 99, 455-460 doi:10.1042/CS20000068

Azevedo L. C., Pedro M. A., Souza L. C., Souza H. P., Janiszewski M., da Luz P. L., Laurindo F. R. (2000): Oxidative stress as a signaling mechanism of the vascular response to injury: the redox hypothesis of restenosis. Cardiovasc. Res. 47, 436-445 doi:10.1016/S0008-6363(00)00091-2

Babál P., Kristová V., Černá A., Janega P., Pecháňová O., Danihel L., Andriantsitohaina R. (2006): Red wine polyphenols prevent endothelial damage induced by CCl4 administration. Physiol. Res. 55, 245-251

Bahcecioglu I. H., Ustundag B., Ozercan I., Ercel E., Baydas G., Akdere T., Demir A. (1999): Protective effect of Ginkgo biloba extract on CCl4-induced liver damage. Hepatol. Res. 15, 215-224 doi:10.1016/S1386-6346(99)00029-7

Benito S., Lopez D., Sáiz M. P., Buxaderas S., Sánchez J., Puig-Parellada P., Mitjavila M. T. (2002): A flavonoid-rich diet increases nitric oxide production in rat aorta. Br. J. Pharmacol. 135, 910-916 doi:10.1038/sj.

Bernátová I., Pecháňová O., Babál P., Kyselá S., Štvrtina S., Andriantsitohaina R. (2002): Wine polyphenols improve cardiovascular remodeling and vascular function in NO-deficient hypertension. Am. J. Physiol. 282, H942-948

Castro A., Ros J., Jiménez W., Clária J., Llibre J., Leivas A., Arroyo V., Rivera F., Rodés J. (1994): Intracellular calcium concentration in vascular smooth muscle cells of rats with cirrhosis. J. Hepatol. 21, 521-526 doi:10.1016/S0168-8278(94)80096-0

Clária J., Jiménez W., Ros J., Rigol M., Angeli P., Arroyo V., Rivera F., Rodés J. (1994): Increased nitric oxide-dependent vasorelaxation in aortic rings of cirrhotic rats with ascites. Hepatol. 20, 1615-1621 doi:10.1002/hep.1840200635

Diebolt M., Bucher B., Andriantsitohaina R. (2001): Wine polyphenols decrease blood pressure, improve NO vasodilatation, and induce gene expression. Hypertens. 38, 159-165

Dimmeler S., Zeiher A. M. (1999): Nitric oxide - an endothelial cell survival factor. Cell Death Differ. 6, 964-968 doi:10.1038/sj.cdd.4400581

Fadhel Z. A, Amran S. (2002): Effects of black tea extract on carbon tetrachloride-induced lipid peroxidation in liver, kidneys, and testes of rats. Phytother. Res. 16, 28-32 doi:10.1002/ptr.793

Fernández-Varo G., Morales-Ruiz M., Ros J., Tugues S., MuňozLuque J., Casals G., Arroyo V., Rodés J., Jiménez W. (2007): Impaired extracellular matrix degradation in aortic vessels of cirrhotic rats. J. Hepatol. 46, 440-446 doi:10.1016/j.jhep.2006.09.023

Fitch R. M., Rutledge J. C., Wang Y. X., Powers A. F., Tseng J. L., Clary T., Rubanyi G. M. (2005): Synergistic effect of angiotensin II and aortic nitric oxide synthase inhibitor in increasing aortic stiffness in mice. Am. J. Physiol. 290, H1190-1198 
Han D. W., Park Y. H., Kim J. K., Lee K. Y., Hyon S. H., Park J. C. (2005): Long-term preservation of human saphenous vein by green tea polyphenol under physiological conditions. Tissue Engin. 11, 1054-1064 doi:10.1089/ten.2005.11.1054

Han D. W., Park Y. H., Kim J. K., Lee K. Y., Hyon S. H., Suh H., Park J. C. (2004): Effects of green tea polyphenols on preservation of human saphenous vein. J. Biotech. 110, 109-117 doi:10.1016/j.jbiotec.2003.12.013

Hlavačková L., Janega P., Černá A., Pecháňová O., Andriantsitohaina R., Babál P. (2009): Red wine polyphenols affect the collagen composition in the aorta after oxidative damage induced by chronic administration of CCl(4). Physiol. Res. 58, 337-344

WHO (1999): International Programme on Chemical Safety: Environmental health criteria. Geneva

Lodovici M., Guglielmi F., Casalini C., Meoni M., Cheynier V., Dolara P. (2001): Antioxidant and radical scavenging properties in vitro of polyphenolic extracts from red wine. Eur. J. Nutr. 40, 74-77 doi:10.1007/PL00007386

Mathie R. T., Ralevic V., Burnstock G. (1996a): Portal vascular responsiveness to sympathetic stimulation and nitric oxide in cirrhotic rats. J. Hepatol. 25, 90-97 doi:10.1016/S0168-8278(96)80333-3

Mathie R. T., Ralevic V., Moore K. P., Burnstock G. (1996b): Mesenteric vasodilator responses in cirrhotic rats: a role for nitric oxide? Hepatol. 23, 130-136 doi:10.1002/hep.510230118

Milovanovic B., Milinic N., Trifunovic D., Krotin M., Filipovic B. Bisenic V., Djuric D. (2009): Autonomic dysfunction in alcoholic cirrhosis and its relation to sudden cardiac death risk predictors. Gen. Physiol. Biophys. 28 (Special Issue), 251-261

Mizutani K., Ikeda K., Kawai Y., Yamori Y. (1999): Extract of wine phenolics improves aortic biomechanical properties in strokeprone spontaneously hypertensive rats (SHRSP). J. Nutr. Sci. Vitaminol. (Tokyo) 45, 95-106

Morales-Ruiz M., Jimenez V., Pérez-Sala D., Ros J., Leivas A., Lamas S., Rivera F., Arroyo V. (1996): Increased nitric oxide synthase expression in arterial vessels of cirrhotic rats with ascites. Hepatol. 24, 1481-1486 doi: $10.1002 /$ hep. 510240630

Ogeturk M., Kus I., Colakoglu N., Zararsiz I., Ilhan N., Sarsilmaz M. (2005): Caffeic acid phenethyl ester protects kidney against carbon tetrachloride toxicity in rats. J. Ethnopharmacol. 97, 273-280

doi:10.1016/j.jep.2004.11.019
Pecháňová O., Bernátová I., Babál P., Martínez M. C., Kyselá S., Štvrtina S., Andriantsitohaina R. (2004): Red wine polyphenols prevent cardiovascular alterations in L-NAME-induced hypertension. J. Hypertens. 22, 1551-1559 doi:10.1097/01.hjh.0000133734.32125.c7

Pourahmad J., Eskandari M. R., Shakibaei R., Kamalinejad M. (2010): A search for hepatoprotective activity of fruit extract of Mangifera indica L. against oxidative stress cytotoxicity. Plant Foods Hum. Nutr. 65, 83-89 doi:10.1007/s11130-010-0161-9

Púzserová A., Csizmadiová Z., Andriantsitohaina R., Bernátová I. (2006): Vascular effects of red wine polyphenols in chronic stress-exposed Wistar-Kyoto rats. Physiol. Res. 55 (Suppl. 1), S39-47

Púzserová A., Csizmadiová Z., Bernátová I. (2007): Effect of blood pressure on L-NAME-sensitive component of vasorelaxation in adult rats. Physiol. Res. 56 (Suppl. 2), S77-84

Souza H. P., Souza L. C., Anastacio V. M., Pereira A. C., Junqueira M. L., Krieger J. E., da Luz P. L., Augusto O., Laurindo F. R. (2000): Vascular oxidant stress early after balloon injury: evidence for increased NAD(P)H oxidoreductase activity. Free Radic. Bio. Med. 28, 1232-1242

doi:10.1016/S0891-5849(00)00240-9

Stocklet J. C., Kleschyov A., Andriambeloson E., Diebolt M., Andriantsitohaina R. (1999): Endothelial NO release caused by red wine polyphenols. J. Physiol. Pharmacol. 50, 535-540

Thrall K. D., Vucelick M. E., Gies R. A. M., Zangar R. C., Weitz K. K., Poet T. S., Springer D. L., Grant D. M., Benson J. M. (2000): Comparative metabolism of carbon tetrachloride in rats, mice, and hamsters using gas uptake and PBPK modelling. J. Toxicol. Env. Health 60, 531-548 doi:10.1080/00984100050082085

Török J., Kristek F. (2001): Functional and morphological pattern of vascular responses in two models of experimental hypertension. Exp. Clin. Cardiol. 6, 142-148

Wiest R., Groszmann R. J. (2000): The paradox of nitric oxide in cirrhosis and portal hypertension: too much, not enough. Hepatol. 35, 478-491 doi:10.1053/jhep.2002.31432

Zenebe W., Pecháňová O., Bernátová I. (2001): Protective effects of red wine polyphenolic compounds on the cardiovascular system. Exp. Clin. Cardiol. 6, 153-115

Received: October 1, 2010

Final version accepted: December 30, 2010 